\title{
The right to translation and interpreting into and from Albanian as a reflection of fundamental civil rights in Kosovo between 1912 and 1999
}

\author{
Arben Shala \\ Charles University, Czech Republic
}

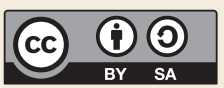

\section{ABSTRACT}

Through the analysis of official legal documentation, this paper presents a historical overview of the development of laws and practices regarding language policies in Socialist Yugoslavia, and the use of the Albanian language in education and in the security sector in Kosovo with special emphasis on translation and interpreting. The results of the analysis show that in the 1970s socialist Yugoslav laws governing the equality of languages in a multilingual state, as codified in the constitution and other administrative and legal documents, were quite progressive on paper but did not entirely translate into political and linguistic equality in practice, but that they, nevertheless, resulted in the increased trust in the formal Kosovo governing institutions; and that the abolishment of translation and linguistic rights accompanied by the abandonment of other fundamental civil rights at the end of the $20^{\text {th }}$ century eventually strengthened the ethnic tensions and divisions in the region. The article concludes that translation and interpreting represent key activities supporting the implementation of linguistic rights and trust in the legal system, and that linguistic rights are effective only if they are supported with other fundamental civil rights, such as the right to education and political participation.

Keywords: linguistic equality, education, translation, constitution, criminal procedure code

\section{Pravica do prevajanja in tolmačenja $v$ albanščino in iz nje kot odraz osnovnih državljanskih pravic na Kosovu med letoma 1912 in 1999}

\section{IZVLEČEK}

$\mathrm{V}$ pričujočem članku je skozi analizo pravnih dokumentov predstavljen zgodovinski pregled razvoja zakonov in praks v zvezi z jezikovnimi politikami v socialistični Jugoslaviji in uporaba albanskega jezika v izobraževanju in v varnostnem sektorju na Kosovu s posebnim poudarkom na prevajanju in tolmačenju. Rezultati analize pokažejo, da je bila zakonodaja, kodificirana $v$ ustavi in $\mathrm{v}$ drugih administrativnih in pravnih dokumentih, ki je regulirala enakopravnost jezikov v večjezični državi, v sedemdesetih letih dvajsetega stoletja v socialistični Jugoslaviji precej napredna na papirju, v praksi pa se ni popolnoma prevedla v politično in jezikovno enakopravnost. Kljub temu pa je ta zakonodaja prispevala k večjemu zaupanju v formalne vladne institucije na Kosovu. Odprava prevajanja in jezikovnih pravic pa je skupaj z odpravo drugih osnovnih državljanskih pravic na koncu dvajsetega stoletja prispevala k krepitvi napetosti in sporov med etničnimi skupnostmi 
na tem območju. V sklepnem delu članka sta prevajanje in tolmačenje izpostavljena kot ključni dejavnosti pri podpori implementaciji jezikovnih pravic in zaupanju v pravni sistem, pri čemer so jezikovne pravice učinkovite le, če jih podpirajo druge državljanske pravice, kot sta pravica do izobrazbe in do političnega udejstvovanja.

Ključne besede: jezikovna enakopravnost, izobraževanje, prevajanje, ustava, kazenski procesni zakonik

\section{Introduction}

The right to language has always been an important part of the human rights agenda in Kosovo. This article describes how during the period between 1912 and 1999 the Albanian language in Kosovo made a full circle: it was first officially banned, its use was then tolerated, for a while it became the main official language, and was finally again officially banned at the end of the twentieth century. The article centres on the history of use of the Albanian language and, consequently on the right to translation and interpreting in education and security sector in Kosovo in the multilingual Yugoslavia. The security sector in a narrow context includes the actors authorised to use force and provide state security and justice, and in a broader context also the actors entitled to oversee and manage them (DCAF 2015, 3). Therefore, the security sector represents an actor that implements state ideologies in asymmetrical power relations with their citizens.

The article analyses legal documents defining the use of the Albanian language and the right to translation and interpreting in the security sector in Kosovo, and compares these legal documents with the historical evidence describing the linguistic landscape of the period. The article therefore aims to describe the development of laws and practices regarding language policies in Socialist Yugoslavia, with particular emphasis on the use of the Albanian language, and the right to translation and interpreting to and from Albanian in the security sector. It is argued in this article that, first, translation and interpreting represent key activities supporting the implementation of linguistic rights and trust in the legal system, and second, that linguistic rights make sense and are effective only if they are consistent with other fundamental rights, such as the right to education and other political rights.

\section{Methodology and corpus}

The methodological approach was adapted to the period investigated. The period before World War II (1912-1945) was studied through a review of eight history books, memoirs, folk culture, and other documents reflecting the major policies related to the Albanian people and language in Kosovo. The second period, from the end of 
World War II until the NATO bombing of targets in the former Yugoslav (i.e. from 1945-1999), was examined through an analysis of legal documents such as constitutions at federal, republican and provincial levels, and other legal documents. The 24 documents were downloaded from the Serbian-based legal database ${ }^{1}$ using keywords for constitution, language, translation, criminal procedure code and criminal code (in Serbian). The identified documents were then converted into machine-encoded text with the help of optical character recognition (OCR) software. Then the documents were analysed using keywords such as language, translation, Kosovo. Following that, the specific sections and articles related to the right to languages and translation were analysed. ${ }^{2}$ There is a potentially minor margin of error for the period between 1945 and 1963 concerning the Criminal Procedure Codes and Criminal Codes, because of the poor quality of the scans available. In order to partly remedy that, all Constitutions and Codes were compared against other existing digital versions.

Several searches in the database, however, yielded no results for two of the crucial documents that marked a positive turning point for Kosovo history under the Yugoslav rule, i.e., the Constitutional Law of Kosovo (1969) and the Law on realisation of equality of languages and scripts (1977), which were missing for unknown reasons. These documents improved and institutionalised linguistic and human rights of the Albanians in Kosovo, therefore they were nevertheless analysed in full.

\section{The use of the Albanian language in Kosovo until 1945}

Before 1912, Kosovo was part of the Ottoman Empire. The Empire policies ${ }^{3}$ did not recognise Albanians and their language as a millet and banned the use of the Albanian language in the educational system, as well as in other administrative and judicial institutions (Malcolm 2011, 182). Although the rulers in Kosovo in Ottoman time (and afterwards) installed their legal systems, scholars argue that they were not accepted at a local level (Salihu et al. 2014, xxxi). In terms of justice, criminal cases were rarely directed to the Turkish authorities (Durham 1909, 29), because the Albanians

1 https://www.uzzpro.gov.rs/

2 I am thankful to my father Nezir Shala for his help with translations from Serbian. He is bilingual and experienced the most troubled times described herein, and was subjected to police brutality as a prisoner of war.

3 The Empire had imposed a millet system grounded in religious adherence, which meant that confessional communities such as Orthodox Christians and Jews were allowed to rule themselves under their own laws. The system granted non-Muslims a certain degree of autonomy and also recognised linguistic rights and ecclesiastical justice (Ceylan 2002, 250-252). 
did not rely on the imposed formal justice system. Instead, the Albanian population administered justice in their own way, through a strict well-established mediation system, a system that did not depend on religious law, but was rather based on a set of rules passed by word of mouth through the centuries. This set of rules constituted a customary law known as Kanuni i Lekë Dukagjinit (the Code of Lekë Dukagjini), which has also impacted, among other areas, the language, as it is still associated with impersonal discourse and many types of references related to institutions and procedures entitled to deliver informal justice (see Shala 2019).

During the Balkan Wars in 1912 and 1913, Serbian forces occupied Kosovo and the northern and central present-day Albania, and reached the Adriatic coast. This period was marked with brutal violence, mass killings and massacres, and displacement of people (Malcolm 2011, 332; Martinović 1977, 256). Just before the Serbian occupation, as a result of changes in the Ottoman Empire, three educational systems existed in Kosovo: Turkish, Albanian and Serbian (Hyseni et al. 2000, 54).

Austro-Hungary and Bulgaria administered Kosovo during World War I (1914-1918). Contrary to the area occupied by Bulgaria, Austro-Hungarian authorities employed Albanians in administration and permitted the use of the Albanian language in education and administration but retained the authority to administer "law and order". Resolutions were read out loud publicly in Albanian (Bajrami 2018, 230-34; Hyseni et al. 2000, 55).

When World War I ended, the Serbian administration was reinstated. The new Serbian government authorities in Kosovo banned education and all other cultural activities in Albanian. They imposed the Serbian educational system and language, while the Albanian language schools were closed in an attempt to facilitate the population's assimilation (Vickers 1998, 103). The illiteracy rate was very high. A small number of Albanian students attended Serbian language schools after a preparatory course. Serbian was the only language used in education, with the exception of Turkish which was allowed in religious instruction for Muslims for some time (Kostovicova 2002). These allowances were a preparatory stage to another step: those who were taught in Turkish were identified as Turkish, dispossessed of their lands and expelled to Turkey (Benson 2004, 67; Judah 2008, 46). This went along with the colonising process and the use of criminal and paramilitary groups against civilians (Malcolm 2011, 329).

During World War I, and in the first years after the end of the conflict, the Albanian resistance movement known as the Kachak (Kaçak) movement was organised, which in certain areas lasted until 1924. Among the requests of the insurgents was that Albanian become the official language in the Kosovo administration (Malcolm 2011, 353). Besides following the political agenda, many people joined the insurgents in their efforts to escape from court or administrative summons or from army duty (Vickers 1998, 100). 
Martinović (1977, 254-59) argues that, contrary to the claims in the Belgrade newspapers of that time, during this period only Serbs were assigned to municipal offices, and that recording clerks were appointed regardless of "their moral and professional qualifications". The same applied to the police officers who tended to have no experience, were not professionals and shared no common grounds with the population. Martinović explains that the judicial system in Kosovo was similar to that in Serbia at the time, which means that the police had the authority to review the judicial sentences issued by a judicial panel, comprising a judge and two citizens who "knew how to read and write, and were from the place the parties in the procedure came from". The latter is ambiguous, however, and could be interpreted differently across the ethnic lines; since Albanian was officially banned, it can be concluded that no translation activities in administrative and judicial settings took place.

The provisions of the Saint Germain treaty on the Protection of Minorities (Article 51), signed in 1919, were never implemented in Kosovo. And even though the Constitution of the Kingdom of Serbs, Croats, and Slovenes (1921) provided that minorities of other races and languages be given basic instruction in their mother tongue (Article 16), that provision did not apply to Kosovo Albanians (Kostovicova 2002, 158). The interwar period was thus one of systematic persecution and of official denial of the existence of the Albanian people and Albanian speakers in Kosovo. The authorities strictly prohibited the use of any language other than Serbian (Hyseni et al. 2000, 55).

These difficult times survived in the collective memory of the Albanians transmitted through historic epic songs named after specific persons, describing the events and the resistance or actions taken against the authorities. In the narratives of the songs the potential communication difficulties with the new authorities are rare, if non-existent, and it seems that the communication takes place without any problems (see Berisha, Fetiu and Ahmeti 1997). This ease in communication could be explained by the long coexistence of different language communities in this area and the historical circumstances under the Ottoman Empire; many Albanians, Serbs, and Turkish people living in larger towns were familiar with all three languages, as were several Montenegrin colonists after World War I. This mutual comprehension lasted until the late 1990s (Munishi 2009, 1007; Petrick 2020).

There was also an ethnic Orthodox population of Albanian origin living in Kosovo (Rizaj 1991, 84). Some of them later returned to the "old faith" (Catholicism) or converted to Islam, however, some of them remained Orthodox (Durham 1909, Judah 2000). During the Balkan wars, many of them joined Serbian forces and identified with them, wore Albanian clothing, were bilingual and also mingled with the local population (Qeriqi 2020). According to the 1921 census, 26\% of the Albanian 
mother-tongue speakers in this area identified themselves as Orthodox Christians (Vickers 1998, 99). According to Martinovic $(1977,274)$, this may also be a reflection of forced conversion policies.

In Albania, after gaining independence in 1912, the use of foreign languages was also allowed in official settings, especially the use of Turkish in the courts and administration. This was because the local employees were educated in foreign languages and did not have the linguistic skills to carry out their work in Albanian (Bylykbashi 1977, 300). Legal proceedings, however, were recorded in Albanian from 1913 (Elsie 2010, 141, 275).

In the spring of 1939, Italy invaded Albania and established the satellite Kingdom of Albania. This included most of Kosovo, the rest was under German control (the north) and Bulgaria (the east). Italians and Germans supported the use of Albanian in education and administration, while Bulgarians replaced the Serbian language with Bulgarian (Vickers 1998, 122). The Italian government imposed their 1939 Constitution on the Albanian Kingdom, maintained old judicial and administrative organisation of King Zog's regime (Fischer 1999, 42), and established a judicial system in Kosovo (OAK 2016). In 1943, an Albanian administration, gendarmerie and a reorganised military force was re-established under German control in Kosovo. The local nationals appointed in the Albanian satellite government were individuals who spoke German and had either lived or studied in Germany or Austria. They assisted the education in Albanian and set an ambitious plan to open 173 Albanian primary and secondary schools. The village elders continued to administer justice and settled most of their affairs on their own (Fischer 1999, 86-7).

A CIA report $(1953,2,6)$ describes the situation under the Axis powers:

During this time a thorough study was made of Serbian administrative laws so they could be synchronised with the Albanian laws. A whole administrative system was created which included courts, the armed forces and police in villages, sports organisations, summer camps for the young, et cetera. [...] More Albanian language books were published in the Kosovo than were published in Albania during her independence.

This was the period when Albanians provided legal services in Kosovo for the first time: and some lawyers from the present-day Albania and a few people from Kosovo provided legal services in Albanian (OAK 2016). Under Italian rule, the establishment of judicial and legislative branches depended on the will of those appointed by the Emperor, and the courts in the Italian-administered area worked according to the Italian Criminal Code of 1930 (Fischer 1999, 42). The Code (Regio Decreto 1930, n. 
1399) had modern provisions related to the language used in procedures, and covered interpreting not only amongst distinct languages but also in cases when rarer dialects were used, even if the judge knew the language (Article 326).

The extent to which these provisions were applied in practice is not known. However, Vehap Shita, a literary critic, journalist and translator born in 1923, recollects that "although it was wartime, the Albanian state [...] worked on the basis of laws, of the Constitution, even though it was the occupiers who were in power" (Shita 2013, 4). The existing literature studying this period usually covers only literary translation, while translation and interpreting for the security sector tends to be overlooked and seen as a medium in service of the enemy and collaborationist policies: people who worked as translators for the authorities of the time were later arrested, interned or executed (cf. Elsie 2010, 141, 186, 445). In addition to this, leading representatives of the Emperor treated the Albanian people and their language with contempt, and described it as a "meaningless dialect" (as quoted in Fischer 1999, 91).

The overview of the use of Albanian in Kosovo, as it is recorded in historical and official documents defining the use of language in administration in the region until the end of World War II, shows that up until 1939 no translation or interpreting services were provided in administrative settings. Nevertheless, the majority of the population in Kosovo understood the three languages spoken in the area: Albanian, Turkish and Serbian. The first grounds for organised linguistic support in judicial settings was introduced during the Italian occupation of the region between 1939 and 1943.

\section{The use of Albanian in education and the security sector in Kosovo between 1945 and 1999}

After World War II, Albanian communists and Kosovo communists (both Albanian and Serbian) forced the German forces out of the land and handed over Kosovo to Yugoslavia (CIA Report 1953, 14). The initial relations between the communist leaders of Albania and Yugoslavia were good. This was also reflected in the attitude of Serb authorities towards Kosovo Albanians. The use of Albanian was allowed, although under the pretext that Albanian language lacked administrative and technical terms it was gradually replaced with Serbian. A state of emergency was imposed in 1945, and Kosovo was under police control until the Yugoslav Minister of Interior, Aleksandar Ranković, was overthrown from power in 1966 (Ryan 2010, 119). The translation of documents was considered a time-consuming and inefficient process, and it did not take long before Serbian became the only language of the administration (CIA report 1953, 12).

The CIA report $(1953,5)$ describes the sentiment about WWII as follows: 
The Kosovars, even though they understood that the Italians and Germans were invaders, nevertheless thank and remember them with sympathy, since it was after all they who gave them freedom to defend themselves against the [...] Communists. This people remains faithful to its national cause, and puts its life at the disposition of any civilized and peace-loving power $[\ldots]$

Under the Federal Constitution of 1946 (Official Gazette of the FPR of Yugoslavia 10/46-73), Kosovo was declared an autonomous region (Article 2), and was officially part of the People's Republic of Serbia (later re-named into a Socialist Republic of Serbia), one of the six republics constituting the Socialist Federal Republic of Yugoslavia. The 1946 Yugoslav Constitution ${ }^{4}$ stipulated that the laws and other regulations were to be published in the language of the nations (i.e., republics) (Article 65). The Constitution mentioned only once the minorities as subjects who "enjoy the right and protection of their cultural development and the free use of their language" (Article 13). The Serbian Constitution ${ }^{5}$ of 1947 (Official Gazette of the PR of Serbia 03/4713) provided that the autonomous region of Kosovo would be governed by a statute (Article 13). The statute and other decision of the autonomous region were to be published in Serbian and in "Šiptarski", i.e., Shqiptar language (Article 115). The use of the mispronounced word Shiptar, which is considered pejorative compared to the word "Albanian", was intentional: it marked an attempt to differentiate between the Albanian language spoken in Kosovo and the Albanian language spoken in Albania, and consequently between Siptari indicating Kosovo Albanians and Albanci referring to those living in Albania (Guzina 2003, 30; Malcolm 2011, 401, 409). During that time, efforts were made to create standard Albanian for Kosovo, based on a variation of the Gheg dialect used by the local press, which would be different even from the Gheg dialect of northern Albania ${ }^{6}$ (Schmitt 2012, 177, 281).

As regards to language used in the courts, the 1946 Yugoslav Constitution provided that the languages of the proceedings should be the languages of the republics, autonomous provinces and autonomous regions where the courts were located, which meant that Slovene, Serbo-Croat and Macedonian were used in courts. Citizens who

4 Socialist Yugoslavia changed its constitution several times: the first one was adopted in 1946, the second in 1953, the third in 1963 and the fourth in 1974.

5 In Socialist Yugoslavia all six republics had a considerable autonomy, which was also manifested in the fact that each republic had its own constitution, which was aligned with the federal Yugoslav constitution (cf. Accetto 2007).

6 There exist two major variants of Albanian: Gheg Albanian, spoken in the northern territories inhabited by Albanians (including Kosovo), and Tosk Albanian, spoken in the South. Standard Albanian is based on Tosk. 
did not know the official language of the republic were to be provided the translation of the entire material and also had the right to interpreting services (Article 120). The same provisions were incorporated into the Serbian Constitution (Article 141). On the one hand, this support of translation and interpreting signalled the Yugoslav government's attempt to establish good relations with Albania. However, on the other the courts were used to set up cases against those who were considered collaborators with the German and Italian forces (according to Article 3 and 4 of the Law of Criminal Offences against the Nation and the State (Official Gazette of the FPR of Yugoslavia 66/45-645)), which often resulted in executions and confiscation of the possessions of the families of the accused (Fetahu 2011,20).

Although legal aid and lawyers' services were offered by Albanian speakers shortly before and after World War II, there were only two or three Albanian speakers offering such assistance. In this period, Kosovo lawyers had to register at the Yugoslav Bar because Kosovo did not have one (OAK 2016). The language used in administration and official communication in Kosovo was Serbian, and the administration and security services employed only Serbs and Montenegrins (Judah 2008, 51). There was high illiteracy among the Kosovo Albanians, and those who knew how to write used Cyrillic script. Efforts against the prevailing illiteracy among Kosovo Albanians were made in the aftermath of World War II, when courses were organised. However, schools remained segregated with separate state schools for Serbs and Albanians (Hyseni et al. 2000, 26-61; Vickers 1998, 152).

The Criminal Code of Yugoslavia $1951^{7}$ (Official Gazette the FPR of Yugoslavia 13/51185) did not have any provision to sanction the violation of linguistic rights, and the same was true of the 1959 Yugoslav Criminal Code (Official Gazette of the FPR of Yugoslavia 30/59-817). When in 1948 Yugoslav relations with Albania deteriorated, ${ }^{8}$ this was reflected in the treatment of the Albanian population in Kosovo: all Albanians in Yugoslavia became subject to surveillance and increased campaigns of police torture and searching for weapons, which intended to subdue and speed up expulsion of Albanians to Turkey (Malcolm 2011, 412). The literacy courses that had been offered to

7 Similarly to the Constitution, Socialist Yugoslavia amended its Criminal Code throughout its history: the first one dates from 1951, the amended ones from 1959 and 1977. In this case as well, each republic had its own Criminal Code that was modelled on the Federal Criminal Code.

8 In 1948 the President of Yugoslavia, Josip Broz Tito, attempted to incorporate Albania into the Yugoslav federation. This led to a conflict with the Soviet Union leadership and resulted in what is known today as the Tito-Stalin split. After 1948 Yugoslavia abandoned numerous political practices created on the Soviet model and started developing its own variant of socialism. This split was also reflected in the amended legislation. 
Albanian population were abandoned, and one of the most common ways an adult illiterate person could learn to read and write became the obligatory time spent in the Yugoslav Army (Islami 1990, 196-206). These oppressive actions went along with the promotion and support of Turkish schools. According to the CIA report (1953, 25), the policies aimed at denationalising the Albanians in Kosovo by promoting the idea that Turkish was a language of culture, while Albanian was a poor language in which cultural development was not possible. The socialist establishment also applied different methods to obstruct the education of Albanian students: for example, the administration delayed the approval of translations of textbooks (all textbooks in that period were translations), had the permission withdrawn for those already approved, or delayed the printing of the textbooks. Teachers were also redeployed to remote areas. Education at secondary and university levels was made obligatory in Serbian schools, in the Serbian language, while $60 \%$ of Albanian students were barred from higher education, especially from the Faculty of Law (CIA Report 1953, 22).

The amended Yugoslav Constitutional Law of 1953 (Official Gazette of the FPR of Yugoslavia 03/53-21) delegated the constitutional powers related to the institution of autonomy to Serbia. Autonomy was no longer a federal matter and Serbia was now entitled to prescribe Kosovo the bases of organisation and the competencies of Kosovo's government bodies (Article 114; Vickers 1998, 155). Consequently, this new Serbian Constitutional Law (Official Gazette of the PR of Serbia 05/53-57) made no reference to the rights to languages and scripts, and declared only that laws were to be adopted and published in the languages of the republics (Article 19). The political reality was again clearly reflected in the translation policy: the deterioration of Yugoslav-Albanian relations was reflected in the cancellation of translation services in administrative settings for the Albanian-speaking population.

However, ten years later the 1963 Constitution (both Yugoslav and Serbian) marked a turn towards greater acceptance of Yugoslav linguistic minorities: it introduced a new term for ethnic minority - nationality - a term used to denote larger minority groups that had a nation state such as Albanians in Kosovo and Hungarians in Vojvodina, while others were known as ethnic groups (Pupavac 2012, 176). The 1963 Yugoslav Constitution (Official Gazette of the FPR of Yugoslavia 14/63-201) thus permitted the introduction of subjects in the languages of the nationalities in secondary and higher education at state institutions and at working organisations (Articles 83, 84, 85) in the areas they lived in. In addition, the conditions were laid for the translation of laws and other regulations into the language of nationalities (Article 86), i.e., also into Albanian.

The status of Kosovo was upgraded to that of an autonomous province, and the current borders were drawn on maps. Many Albanian speakers in Yugoslavia were left out and 
remained citizens of the Republic of Macedonia and Montenegro and also of south Serbia (Schmitt 2012, 177). The 1963 Yugoslav Constitution, by considering the languages of the nations (not nationalities) of Yugoslavia and their scripts as equal, defined the official languages of Yugoslavia as Serbo-Croat, Slovene and Macedonian. These languages were considered equal, except in the Yugoslav Army, where Serbo-Croatian was to be used in the command, military training and administration (Article 42).

After the removal, in 1966, of the Minister of the Interior of Yugoslavia, Aleksandar Ranković, who was a proponent of centralised Yugoslavia and Serbia, the newly applied decentralisation policies facilitated discussions about linguistic and ethnic divisions and also about other political and administrative functions (Tollefson 1980). During this period there were attempts to divide between a language and a national identity and to promote the Yugoslav supranational identity, and also to distance from the former policies of the Kingdom of Yugoslavia and those of Ranković. However, not only Albanians but also Croatians, Macedonians and Slovenes felt their languages were endangered by the Belgrade version of Serbo-Croatian (Benson 2004, 112; Vickers 1998, 104), as thus was the language spoken by $70 \%$ of the former Yugoslav people (Pupavac 2012, 180), making it an unofficial lingua franca of the entire Yugoslavia, including Kosovo.

Generally, it was expected that when Serbs and Albanians communicate, they did it only in Serbian (Malešević-Didarja 2016). This expectation reflected the fact that in this period $70 \%$ of the subjects in elementary education attended by Albanian students in Kosovo were in Serbian and were taught by Serb and Montenegrin teachers (Hyseni et al. 2000, 60). Serbo-Croatian was a mandatory subject in primary and secondary schools, and the only language of education at university levels. The first higher education institution established in Kosovo was the Faculty of Law and Economics in 1961, but until 1966 the language of instruction remained Serbian (Kostovicova 2005, 42).

In 1967 and 1968, the protests of the Albanian population started, demanding for Kosovo the status of a republic, their own constitution and the right to self-determination (Novosella 2019). Although suppressed, the protests resulted in significant concessions granted in favour of the Albanians (Malcolm 2011, 410). The 1968 Yugoslav Constitutional Amendments (Official Gazette the SFR of 55/68-1293) thus made Kosovo an integral part of Yugoslavia (amendment vii). The rights and duties of the province were determined by the Provincial Constitutional Law (amendment xviii). The rights comprised the application of equality of languages and scripts of peoples and nationalities in the areas they lived in, and their right to use their language in court proceedings and local government (amendment xix). Again, greater political freedom was directly reflected in the local language and translation policies. 
In line with this, the Kosovo Assembly passed the Kosovo Provincial Constitutional Law in 1969. The law provided more freedom to draft laws (Article 85), which were considered authentic in the three languages (Article 82). The provision that institutions of higher education could join to form a university was another remarkable advancement (Article 25) and laid the foundations of the University of Prishtina. The Kosovo Provincial Constitutional Law also provided the equality of the Albanian, Serbian and Turkish languages and their scripts (Article 10). It emphasised the principle of the equality of the languages and their scripts in use by all institutions in Kosovo (Article 70), and enacted the rights to the use of the parties' native languages in the court procedure. The parties had the right to use their own language and be informed about the facts in the procedure in their native languages (Article 74). This also applied for the submission of petitions, complaints and other submissions to government institutions and other organisations exercising public authority. The members of these linguistic communities were allowed to receive the responses and other acts that imposed rights and duties on them in their own languages.

To comply with the changes, many bylaws (regulations, decisions and other relevant documents) were issued that led to a boost of translation into Albanian. The Provincial Secretariat for Law and Justice approved the regulation on permanent court interpreters (Official Gazette of the SAP of Kosovo 38/69-1305), and on taking exams for permanent court interpreters (Official Gazette of the SAP of Kosovo 07/70-248). The latter laid down the qualifications and requirements for the exams for permanent court interpreters. Besides linguistic skills, it required the translation of 5,200 characters per hour. The commission considered the written part correct if it did not require the intervention of a reviewer. The test comprised the translation of a legal and a general text. This test required the candidates to deliver a literal translation, pay attention to the syntax of the target language, manifest sufficient knowledge of the legal terminology, and avoid embellishments in their lexical choices (Article 10). The oral exam (checking the interpreting and communication skills) lasted 15 minutes and was to be taken the following day after the results of the written test were delivered (Article 13).

In 1971, the Serbian Law governing the rights of members of nationalities to use their language and script in the republican government bodies (Official Gazette of the SR of Serbia 14/71-343) was passed. It provided that the records of the procedure be taken in the Serbo-Croatian language and only parts of them be translated in the language of the nationalities, if requested. Interpreting in court proceedings was to be conducted by permanent court translators. It was also possible to appoint persons who were not permanent court interpreters, provided that they could translate from Serbo-Croatian to the language of a nationality (Articles 3 and 4). 
During this period Kosovo Albanians adopted the Albanian standard language, and the cultural exchange and cooperation between Kosovo and Albania increased. In addition to this, the Yugoslav Constitution of 1974 granted sovereign rights to the provinces to exercise executive, legislative, and judicial functions (Weller 2011, 83). In legal terms, Kosovo obtained a status that was almost equal to that of the republics, but in practice the Serbian authorities arbitrarily and unconstitutionally reduced its powers and competencies, especially those related to police, judiciary and legislation (Salihu et al. 2014, xxxiii). Kosovo Serbs viewed this and other constitutional changes that followed with suspicion and discontent, and saw this opening as a first step towards unification of Kosovo with Albania (Greenberg 2004, 12).

The Yugoslav Constitution of 1974 (Official Gazette of the SFR of Yugoslavia 09/74209) marked further liberalisation of the language and translation policy: it emphasised the equality of citizens before the law (Article 154), freedom to display their ethnic and cultural backgrounds, and deemed unconstitutional and penalised ethnic or cultural hatred and intolerance. The languages of all the nations and nationalities and their scripts were considered equal (Articles 170, 246), and their use in public institutions and education was entitled (Article 171). The constitution provided the equality of languages even in the international communication (Article 271). In court proceedings, the parties were entitled to their rights to language "in the course of proceedings", while Serbo-Croatian lost the privilege as the exclusive language of command and military training (Article 214). The laws, in addition to the languages of nations, were translated and also deemed authentic in the languages of the nationalities (Albanian and Hungarian) (Article 260).

The Criminal Code of Yugoslavia 1976 (Official Gazette of the SFR of Yugoslavia 44/76-1329) even sanctioned violations of linguistic rights with a prison term of three months to less than five years. The same violation is included in the Criminal Code of Serbia (Official Gazette of SR of Serbia 26/77-1341), and the sentence for the denial to exercise linguistic rights to nationalities was imprisonment of up to one year (Article 61).

The Yugoslav Code of Criminal Proceedings (Official Gazette of the SFR of Yugoslavia 04/77-145) provided that petitions or complaints could be submitted before the court in the languages of the nations and nationalities (Article 6). The criminal proceedings were to be provided in the official language of the court. The parties during the pre-trial procedure and the main hearing were allowed to use their own languages with interpreting and translation of documents provided. There was a waiver option to linguistic rights if the party knew the language of the court (Article 7). 
The Criminal Code of Kosovo (Official Gazette of the SAP of Kosovo 20/77-547) was even more stringent regarding the violation of linguistic rights. In the section governing the criminal offences against human rights, the violation of equality of languages and scripts was sanctioned with imprisonment. Therefore, a denial or limitation to the equal use of language or script could lead to imprisonment from one year to up to three years if the denial was enforced by an administrative official (Article 45).

The abovementioned provisions were also incorporated in the Law on Criminal Procedure of Yugoslavia (Official Gazette of the SFR of Yugoslavia 26/86-789). The provisions also regulated in detail the inter-court communication between republics and/ or autonomous provinces (Article 9). Petitions and submissions were to be delivered in the language of the respective nationality (Articles 5, 6, 8), which was made possible by enabling translation and interpreting services. The denial of the use of the native language of the parties in legal procedures was deemed an essential violation of the provisions of the criminal procedure (Article 364): the parties in proceedings were to be informed of their right to interpreting (Article 7), and the expenses of interpreting services were not to be collected from the parties involved (Article 95).

The Constitution of Kosovo of 1974 (Official Gazette of the SAP of Kosovo 04/74-75) stated that all nations and nationalities in Kosovo had equal rights and duties to display their national affiliation, cultural specifics, and history (Article 4). It recognised as equal the use of the Albanian, Serbian and Turkish languages and scripts (Article 5 \& 187) in administration, governmental bodies, state-owned enterprises (Article 217), and education (Article 218). The equality of languages also applied to court proceedings (Article 236).

The changes improved the education and economy in Kosovo. For the first time, Albanian-speaking women were employed in administration, although they were excluded from leading positions. This led to the loss of influence of the traditional law on the Albanian social life in Kosovo (Schmitt 2012, 214-215). Albanians also took over the leading roles in the economy and state mechanisms, including the police, which during this time consisted mainly of Albanians. However, state security remained in the hands of Serbs and Montenegrins (Benson 2004, 137).

Before 1974, Kosovo lawyers had to be admitted to the Yugoslav Bar Association if they wanted to practice law. Due to the political situation, the lack of lawyers of Albanian ethnicity imposed the use of Serbian in legal settings. In 1973, however, the Kosovo Bar Association was established (Official Gazette of the SAP of Kosovo 43/731253) and admitted the first lawyer of Albanian ethnicity in 1974. After this period, the number of Albanian-speaking lawyers increased (OAK 2016). The statute of Kosovo Bar Association (Official Gazette of the SAP of Kosovo 23/78-645) provided 
that the Albanian and Serbo-Croatian languages and scripts were in equal use in the work of the Bar and its head office (Article 17).

The Kosovo Law on realisation of equality of languages and scripts of 1977 (Official Gazette of the SAP of Kosovo 48/77-1335) provided that proceedings before a court or another governmental agency were to be conducted in the Albanian and Serbo-Croatian languages, while in the areas with Turkish populations were also to be conducted in Turkish (Article 5). If speakers of different languages could not agree on the language of the proceedings, the law provided that the presiding judge would decide which one to use.

This overview of the legal documents regulating language and translation policy in Kosovo in the 1970s shows that in theory the Yugoslav, Serbian and Kosovo legislation guaranteed equal status of three languages in Kosovo: Albanian, Serbian and Turkish. This equality was to be enabled by a free state provision of translation and interpreting services. However, these linguistic provisions were rarely used in practice in Kosovo, and there have been several reports of violations regarding the use of Albanian in the legal proceedings (Fetahu 2011, 77): for example, if one party in a procedure was Serbian, regardless of whether the presiding judge was Serbian or Albanian, the proceedings were always held in Serbian. And if the parties were Albanian and the presiding judge Serbian, the proceedings were held in Serbian too (Fetahu 2011, 78). Actual practice thus reflected that in that period Serbian was more equal than other languages.

In 1981, large-scale demonstrations by Albanians broke out in Kosovo because of social inequality. The protests soon turned into a political revolt, with fierce repression by the provincial, republican and federal forces. Many students, teachers and others were arrested and sentenced to long prison terms (Bellamy 2002, 6).

At that time the policy of ideological-political differentiation ${ }^{9}$ and a bilingualism criterion demanding that all Kosovo government officials know Serbian and Albanian were also introduced, with considerable impact on Kosovo's linguistic communities. The Serbian community that had had no need of Albanian before, was now at a loss, while the bilingualism of the Albanian population represented an advantage. The vast majority of the Serb community thus failed to meet with bilingual requirements and could not get government positions (Vickers 1998, 215). In addition, the progress and education of Albanians led to a competition between Serbian and Albanian graduates for leading positions in Kosovo. This loss of privileges was further fuelled by Belgrade media, especially after 1981 (cf. Đokić 2019). Another factor was the adoption

9 In other words, the alienation of government officials with inappropriate political views and ideas, which resulted in their discharge from employment and thus loss of livelihood. 
of standard Albanian, based on the Tosk dialect, one that those Kosovo Serbs who spoke Albanian did not understand (Vickers 1998, 176). These tensions proved to be a fertile ground for the formation of the political position of Slobodan Milošević. Milošević, at that time President of the Serbian League of Communists (1986-1989), used the support of Kosovo Serbs to justify his actions and implement his centralist policies. In a speech in 1987 he said that he would impose changes to everything in question, "from the beginning to the end, from kindergartens to courtrooms", including rights, freedom, culture, language and scripts (Milošević 1987). In another speech from 1989, Milošević claimed that the "lack of unity" was the reason why Serbia could not prosper, and that he would therefore remove national divisions to facilitate the elimination of "other divisions" (Milošević 1989).

When Milošević became President of the Presidency of the Socialist Republic of Serbia (1989-1991), Kosovo was the first victim and changes were soon introduced. Autonomy was abolished, and Kosovo became just another region of Serbia. The courts located in the areas with an Albanian majority were dissolved, while the rest were turned into branches of courts in Serbia (Fetahu 2011, 309-10). The substantial changes sanctioned the supremacy of the Serbian language and the Serb nation, and arbitrariness prevailed. Abruptly, the use of Albanian for official purposes was discontinued and Serbo-Croatian was declared the official language of Kosovo (Greenberg 2004, 164). According to the 1990 Constitution of Serbia (Official Gazette of the R. of Serbia 01/90-1), only the Serbo-Croatian language and the Cyrillic script were allowed for official use, while nationalities had the right to use their language only in their own areas (Article 8).

The Law on realisation of equality of languages and scripts (Official Gazette of the SAP of Kosovo 48/77-1335) was repealed and replaced by a new one, issued by the Serbian Assembly (Official Gazette of Republic of Serbia 45/91-1802). The law included certain provisions relating to the language rights of nationalities in court proceedings, but they were intentionally inapplicable due to changes in the judicial structure mentioned above. The law specified that all legal procedures of the first (Article 12) and second instances were to be conducted in Serbian, with the decisions of the second instance translated into the languages of the parties (Article 15). The records were to be taken only in Serbian, while a member of another nationality would be provided with a translation of the minutes or of its parts only if requested (Article 17). These provisions were a considerable step back even from the 1971 law governing the rights of members of nationalities to use their languages and scripts in the republican government bodies (Official Gazette of the SR of Serbia 14/71-343). According to Fetahu $(2011,78)$, the new law was discriminatory and gave the opportunity for abuse also because it privileged the use of the Cyrillic script. Until that time, Serbian in legal 
proceedings in Kosovo was usually written in Latin script. Moreover, the law was in contradiction with the Yugoslav Federal Constitution still into force at that time, which considered equal all the languages of the various nations and nationalities and their scripts in the territory of Yugoslavia (Article 246 (1)).

Further limitation of political liberties in Kosovo went hand in hand with the limitation of the rights to translation and interpreting. The equality of languages and scripts granted under Article 61b of the 1986 amendments of the Serbian Criminal Code (Official Gazette of SR of Serbia 39/86-2739) was revoked. With these legal actions the short 15-year period when the Kosovo judicial system had flourished (1974-1989) ended. Belgrade took over the judiciary, police forces and provincial administration, while the Albanian schools were closed. The ethnic division reduced the opportunities for language contacts. A parallel education system was established which, accompanied by increased ethnic violence, fostered the sentiment of a complete break-up with Serbia (see Salla 1995). This break-up in the education system meant that Albanian students would not learn Serbian any longer, while Serb students were never required to learn Albanian in their schools. The linguistic gap between the communities increased, so that now younger Albanians and Serbians in Kosovo do not speak the language of the other community (IOM Report 2018, 9).

In judicial matters, the segregation policies directed against the Albanian population in Kosovo during the 1990s compelled people to seek justice in other ways, outside the legal system (Kostovicova 2005, 40-77). This was a throwback because people took the law into their own hands and avoided formal institutions, as they had done before 1974. The old traditional law remained, most of the times, the only way of regulating the lives of Albanian people in Kosovo (Kostovicova 2005, 116) until the war broke out in 1998.

In 1992 Socialist Yugoslavia collapsed, and the Federal Republic of Yugoslavia, consisting of the former socialist republics of Serbia and Montenegro was formed. In 1998 a full-fledged war broke out in Kosovo, and many Albanians living there were captured by the Yugoslav military, paramilitary and police forces. Many bilingual people were forced to take the role of interpreters to pass on the threats and commands of the Serbian forces before they were killed along with other captured civilians. Those who were not, went through mock trials and were forced to sign papers "admitting their crimes of terrorism" in a language they did not understand. Those who knew both languages were not allowed the read the papers; furthermore, no translation and interpreting services were provided during court sessions (HRW 2001, 191; OSCE/ ODIHR 1999, 47, 80,191). Again, the curtailing of civil liberties went hand-in-hand with the limitation of the rights to translation and interpreting. 


\section{Conclusions}

Kosovo has seen long periods where distinct languages and their speakers lived peacefully side by side, and when bilingualism, translation and interpreting were essential requirements in the security sector. However, it has also seen periods of hegemony of one language over the other languages spoken in the region.

The use of the Albanian language in the security sector in Kosovo passed through complex stages of historical development throughout the period from 1912 until 1999. If in the period before the Italian occupation the use of Serbian in official settings in Kosovo was the norm, the situation changed afterwards, and different governments during and after World War II provided or abolished translation and interpreting in official settings. The first legal grounds for interpreting support in judicial settings were introduced during the time of the Kingdom of Albania between 1939 and 1943. After World War II, when Kosovo became a part of Yugoslavia, the right to translation and interpreting and the use of languages of the various nationalities in legal proceedings was, in general, acknowledged in the codified laws. However, in practice, more often than not these linguistic rights failed to be appropriately implemented.

The review of documents also showed that civil rights and the right to higher education went parallel with the right to translation and interpreting as an implementation of linguistic rights and policies, and that an effective exercise of the right to translation promoted trust in the security sector. For example, in the 1970s the progressive development of linguistic and translation rights and the participation of Albanian speakers in the security sector led to increased trust in the sector. While in the 1990s, when the linguistic rights of Kosovo Albanians were curtailed and eventually the right to translation and interpreting was almost completely abolished, this resulted in exacerbated nationalist feelings which led to a military conflict.

The analysis presented in this study thus shows that translation and interpreting represent key activities supporting the implementation of linguistic rights and trust in the legal system, but also that linguistic rights are effective only if they are supported with other fundamental civil rights such as the right to education and political participation.

\section{References}

Accetto, Matej. 2007. "On Law and Politics in the Federal Balance: Lessons from Yugoslavia." Review of Central and East European Law 32: 191-231. https://doi. org/10.1163/092598807X165622.

Bajrami, Hakif. 2018. Shqiptarët në luftë për shtet kombëtar (1912-1918). Prishtinë: Faik Konica. 
Bellamy, Alex J. 2002. Kosovo and International Society. New York: Palgrave Macmillan. Benson, Leslie. 2004. Yugoslavia: A Concise History. New York: Palgrave Macmillan.

Berisha, Rrustem, Sadri Fetiu, and Jahir Ahmeti. 1997. Rizah Bllaca, Këngë popullore 3. Prishtinë: Instituti Albanologjik i Prishtinës.

Bylykbashi, Zija. 1977. "Komisioni Ndërkombetar i Kontrollit (KNK) dhe veprimtaria e tij (1913-1914)." Gjurmime albanologjike: Seria e shkencave historike 7: 281-304.

Ceylan, Ebubekir. 2002. “The Millet System in the Ottoman Empire." In The Millennium Perspectives in the Humanities, edited by Judi Upton-Ward, 245-66. Utah: Global Humanities Press.

CIA(Central IntelligenceAgency).1953. Albanian Minorityin Yugoslavia. Report50X1-HUM. CIA https://www.cia.gov/readingroom/docs/CIA-RDP82-00457R014500140002-8.pdf. Accessed July 4, 2020.

Codice di Procedura Penale. 1930. Accessed April 5, 2020. https://www.gazzettaufficiale.it/ eli/id/1930/10/26/030U1399/sg.

DCAF, (Geneva Centre for the Democratic Control of Armed Forces). 2015. The Security Sector: Roles and Responsibilities in Security Provision, Management and Oversight. Accessed April 2, 2020. https://www.files.ethz.ch/isn/195675/DCAF_BG_3_The\%20 Security\%20Sector.11.15.pdf.

Đokić, Bojan. 2019. "Srpska javnost o međunacionalnim odnosima u Socijalističkoj Autonomnoj Pokrajini Kosovo 1981-1989.” PhD diss., University of Novi Sad.

Durham, Mary E. 1909. High Albania. London: Edward Arnold.

Elsie, Robert. 2010. Historical Dictionary of Albania. Lanham (Maryland): The Scarecrow Press.

Fetahu, Adil. 2011. Krijimi dhe rrënimi i gjyqësorit të Kosovës. Prishtinë: Lidhja e Juristëve të Kosovës.

Fischer, Bernd J. 1999. Albania at War, 1939-1945. London: C. Hurst \& Co.

Greenberg, Robert D. 2004. Language and Identity in the Balkans. Oxford: Oxford University Press.

Guzina, Dejan. 2003. "Kosovo or Kosova - Could It Be Both?: The Case of Interlocking Serbian and Albanian Nationalisms." In Understanding the War in Kosovo, edited by Florian Bieber and Židas Daskalovski, 31-52. London: Routledge.

HRW (Human Rights Watch). 2001. Under Orders: War Crimes in Kosovo Part 2. New York: Human Rights Watch.

Hyseni, Halim, Bajram Shatri, Jonuz Salihaj, and Dukagjin Pupovci. 2000. Shifra e fakte për arsimin në Kosovë, Prishtinë: QAK.

IOM (International Organization for Migration). 2018. Communication among Members of Serbian and Albanian Communities in Kosovo - The Issue of Languages. Accessed April 10, 2020. https://www.kosovo.iom.int/issue-languages-communication-among-members-serbian-and-albanian-communities-kosovo-public-opinion. 
Islami, Hivzi. 1990. Kosova dhe Shqiptarët: çështje demografike. Rilindja: Prishtinë.

Judah, Tim. 2000. The Serbs: History, Myth and the Destruction of Yugoslavia. New Haven: Yale University Press.

Judah, Tim. 2008. Kosovo: What Everyone Needs to Know. Oxford: Oxford University Press.

Kostovicova, Denisa. 2002. "Shkolla shqipe' and Nationhood: Albanians in Pursuit of Education in the Native Language in Interwar (1918-41) and Post-Autonomy (198998) Kosovo." In Albanian Identities: Myth and History, edited by Stephanie Schwandner-Sievers and Bernd Jürgen Fischer, 157-71. London, UK: Hurst \& Co.

Kostovicova, Denisa. 2005. Kosovo: The Politics of Identity and Space. London: Routledge. Krivični zakon SAP Kosova 1977. Official Gazette of the Socialist Autonomous Province of Kosovo: 20/77-547.

Krivični zakon SFRJ. 1976. Official Gazette of the Socialist Federal Republic of Yugoslavia: 44/76-1329.

Krivični zakon SR Srbije. 1977. Official Gazette of the Socialist Republic of Serbia: 26/771341.

Krivični zakon. 1959. Official Gazette of the Federal People's Republic of Yugoslavia: 30/59-817.

Krivični zakonik. 1951. Official Gazette of the Federal People’s Republic of Yugoslavia: 13/51-185.

Ligja Kushtetuese të Krahines Socialiste Autonome të Kosovës. 1969. Official Gazette of the Socialist Autonomous Province of Kosovo.

Ligji për realizimin e barazisë së gjuhëve dhe shkrimeve. 1977. Official Gazette of the Socialist Autonomous Province of Kosovo: 48/77-1335.

Malcolm, Noel. 2011. Kosova, një histori e shkurtër [Kosovo: A Short History]. Translated by Avdullah Karjagdiu and Pirro Misha. Prishtinë: Koha.

Malešević-Didarja, Miroslava. 2016. The Life Story of a Woman from Prizren. Translated by Shkelzen Maliqi. Accessed April 18, 2020. https://oralhistorykosovo.org/didarathe-life-story-of-a-woman-from-prizren/.

Martinović, Sreten. 1977. "Qëndrimi i ushtrise serbe ndaj shqiptareve në viset e pushtuara në vitet 1912-1913 [Le comportement de l'armee Serbe envers les Albanais dans les regions ocupees 1912-1913]." Gjurmime albanologjike: Seria e shkencave historike 7: $247-80$.

Milošević, Slobodan. 1987. Speech of Slobodan Milosevic at Kosovo Polje. Accessed June 4, 2020. http://www.slobodan-milosevic.org/news/milosevic-1987-3-eng.htm.

Milošević, Slobodan. 1989. Govor Slobodana Miloševića na Gazimestanu 1989. godine. Accessed June 4, 2020. http://www.pecat.co.rs/2011/06/govor-slobodana-milosevica-na-gazimestanu-1989-godine/. 
Munishi, Shkumbin. 2009. "Barazia e gjuhëve në Kosovë dhe perspektiva evropiane." Uluslararası Balkanlarda tarih ve kültür kongresi 10-16 Mayıs '09 Kosova - Priştine: bildiriler kitabı 1: 989-1012. Sakarya: Sakarya Universitesi.

Novosella, Selatin. 2019. Viti 1968, vit i kthesës së madhe historike. Accessed June 10, 2020. https://www.epokaere.com/viti-1968-vit-i-ktheses-se-madhe-historike/.

OAK (Oda e Avokatëve të Kosovës). 2016. Misioni \& Historiku. Accessed June 10, 2020. http://www.oak-ks.org/sq/rreth-nesh.

OSCE (Organization for Security and Co-operation in Europe) and ODHIR (Office for Democratic Institutions and Human Rights). 1999. Kosova/Kosovo: As Seen, as Told. Warsaw: OSCE.

Petrick, Daniel. 2020. Rikthim në Kosovë: Serbët që u rikthyen në qytetin e tyre të lindjes. Accessed May 10, 2020.https://balkaninsight.com/2020/01/14/rikthim-ne-kosoveserbet-qe-u-rikthyen-ne-qytetin-e-tyre-te-lindjes/?lang=sq.

Praviljnik o polaganju ispita za stalne sudske tumače. 1970. Official Gazette of the Socialist Autonomous Province of Kosovo: 07/70-248.

Pupavac, Vanessa. 2012. Language Rights: From Free Speech to Linguistic Governance. New York: Palgrave Macmillan.

Qeriqi, Ahmet. 2020. A ishte Kryeçetniku, Kosta Peçanac, me origjinë shqiptar ortodoks, nga radha e laramanëve fetarë? II. Accessed May 15, 2020. https://www.radiokosovaelire.com/a-q-a-ishte-kryecetniku-kosta-pecanac-me-origjine-shqiptar-ortodoks-ngaradha-e-laramaneve-fetare-ii/

Rizaj, Skender. 1991. Shqiptarët dhe Serbët në Kosovë [Albanians and Serbs in Kosova]. Prishtinë: Zëri i Rinisë.

Ryan, Barry J. 2010. "Policing the State of Exception in Kosovo." In Kosovo, Intervention and Statebuilding, edited by Aidan O'Hehir, 114-31. London: Routledge.

Salihu, Ismet, Hilmi Zhitija, and Fejzullah Hasani. 2014. Komentari i Kodit Penal të Republikës së Kosovës. Deutsche Gesellschaft für Internationale Zusammenarbeit (GIZ) $\mathrm{GmbH}$.

Salla, Michael. 1995. "Kosovo, Non-violence and the Break-up of Yugoslavia." Security Dialogue 264: 427-38. https://doi.org/10.1177/0967010695026004008.

Schmitt, Oliver J. 2012. Kosova: Histori e shkurtër e një treve qendrore ballkanike. [Kosovo. Kurze Geschichte einer zentralbalkanischen Landschaft]. Translated by Enver Robelli Prishtinë: Koha.

Shala, Arben. 2019. “Translating Culture: Mediating Customary Law Related Language." Acta Universitatis Carolinae - Philologica 4, Translatologica Pragensia 93-106. https:// doi.org/10.14712/24646830.2020.8.

Shita, Vehap. 2013. Interview with Vehap Shita. Accessed March 1, 2021. https://oralhistorykosovo.org/wp-content/uploads/2016/04/Vehap_Shita_eng.docx.pdf. 
Statut Advokatske Komore Kosova. 1978. Official Gazette of the Socialist Autonomous Province of Kosovo: 23/78-645.

Tollefson, James W. 1980. "Language Policy and National Stability in Yugoslavia." Canadian Slavonic Papers / Revue Canadienne Des Slavistes 22 (4): 506-17.

Treaty of Peace between the Principal Allied and Associated Powers and Austria (Signed At St. Germain-En-Laye).1919. Accessed March 15, 2020. https://jusmundi.com/en/ document/treaty/en-treaty-of-saint-germain-1919-treaty-of-saint-germain-1919wednesday-10th-september-1919.

Uredba o stalnim sudskim tumačima.1969. Official Gazette of the Socialist Autonomous Province of Kosovo: 38/69-1305.

Ustav Federativne Narodne Republike Jugoslavije. 1946. Official Gazette of the Federal People's Republic of Yugoslavia: 10/46-73.

Ustav Kraljevine Srba, Hrvata i Slovenaca. 1921. Accessed April 1, 2020. http://www.arhivyu.gov.rs/active/sr-latin/home/glavna_navigacija/leksikon_jugoslavije/konstitutivni_akti_jugoslavije/vidovdanski_ustav.html.

Ustav Narodne Republike Srbije. 1947. Official Gazette of the People's Republic of Serbia: 03/47-13.

Ustav Republike Srbije. 1990. Official Gazette of the Republic of Serbia: 01/90-1.

Ustav SAP Kosova. 1974. Official Gazette of the Socialist Autonomous Province of Kosovo 04/74-75.

Ustav Socijalističke Federativne Republike Jugoslavije. 1963. Official Gazette of the Socialist Federal Republic of Yugoslavia: 14/63-201.

Ustav Socijalističke Federativne Republike Jugoslavije. 1974. Official Gazette of the Socialist Federal Republic of Yugoslavia: 09/74-209.

Ustavni zakon o osnovama društvenog i političkog uređenja Federativne Narodne Republike Jugoslavije i saveznim organima vlasti.1953. Official Gazette of the Federal People's Republic of Yugoslavia: 03/53-21.

Ustavni zakon o osnovama društvenog i političkog uređenja i o organima vlasti Narodne Republike Srbije. 1953. Official Gazette of the PR of Serbia: 05/53-57.

Ustavni zakon za provodenje ustavnih amandmana 8 i 16.1968. Official Gazette the Socialist Federal Republic of Yugoslavia: 55/68-1293.

Vickers, Miranda. 1998. Between Serb and Albanian: A History of Kosovo. London: Hurst \& Co.

Weller, Marc. 2011. Shtetësia e kontestuar: administrimi ndërkombëtar i luftës së Kosovës për pavarësi [Contested statehood: Kosovo's struggle for independence]. Translated by Flaka Surroi. Prishtinë: Koha.

Zakon o advokaturi i drugoj pravnoj pomoci. 1973. Official Gazette of the Socialist Autonomous Province of Kosovo: 43/73-1253. 
Zakon o izmenima i dopune krivičnog zakona SR Srbije. 1986. Official Gazette of the Socialist Republic of Serbia: 39/86-2739.

Zakon o krivični delima protiv naroda i države. 1945. Official Gazette of the Federal People's Republic of Yugoslavia: 66/45-645.

Zakon o krivičnom postupku 1977. Official Gazette of the Socialist Federal Republic of Yugoslavia: 04/77-145.

Zakon o krivičnom postupku. 1986. Official Gazette of the Socialist Federal Republic of Yugoslavia: 26/86-789.

Zakon o načinu ostvarivanja prava pripadnika narodnosti na upotrebu svog jezika i pisma kod republickkih organa.1971. Official Gazette of the Socialist Republic of Serbia: 14/71343.

Zakon o službenoj upotrebi jezika i pisama. 1991. Official Gazette of the Republic of Serbia: 45/91-1802.

\section{About the author}

Arben Shala is a PhD student at Charles University in Prague, the Czech Republic. He worked as a Language Assistant, for more than 18 years, with different units of the Police Component of the United Nations Mission in Kosovo (UNMIK) and European Union Rule of Law Mission in Kosovo (EULEX). His research interests are legal translation and interpreting, intercultural communication and the history of translation. His ongoing $\mathrm{PhD}$ research focuses on the role of language assistants in international (peacekeeping and peacebuilding) police missions in Kosovo. He is a freelance translator and has worked as Public Relations Officer at Gllogovc Municipality in Kosovo. At present, he is the Deputy Mayor of Drenas/Gllogovc Municipality in Kosovo. 